\title{
Suppressive Effects of an Ishige okamurae extract on 3T3-L1 Preadipocyte Differentiation
}

\author{
Sun-yeong Cha and ${ }^{\dagger}$ Yong-Pil Cheon \\ Division of Developmental Biology and Physiology, School of Biosciences and Chemistry, \\ Sungshin Women's University, Seoul 142-742, Republic of Korea
}

\begin{abstract}
The biological activity of tissue specific stem cell is under the control of their specific microenvironment and the exogenous chemicals derived from digestive tract can be one of the constructing factors of that. It is suggested that the extract of brown algae Ishige okamurae has antioxidant-, apoptosis induction-, and antiinflammatory- effects. On the other hand, a few studies have shown that antioxidant assist inhibition of accumulation of fat. So we studied the effect of the extract of I. okamura on the cellular activity and differentiation of 3T3-L1 preadipocyte to adipose cell. The viability of cell was analyzed using 3-[4,5-dimethylthiazo-2-yl]-2,5-diphenyl tetrazolium bromide (MTT) assay. Adipogenesis of 3T3-L1 cell was analyzed after induction in the induction medium containing the $I$. okamurae extract. The cellular activity was high compared with the vehicle and $0.05 \mathrm{mM}$ caffeine in all groups of $I$. okamurae extract treated cells. The extract of $I$. okamura inhibited accumulation of lipids in 10 and $50 \mu \mathrm{g} / \mathrm{ml}$. The expression of the marker genes for adipocyte differentiation coincided with cytochemical results. These results suggest that the extract of I. okamurae increases the cellular viability of adipose precursor cells. On the other hand, it suppresses the differentiation of preadipocyte to adipocyte and accumulation of lipids in concentration-dependent manners. It may be possible that the major component of the extract can be applied in the control of adipose tissuegenesis.
\end{abstract}

Key words : Extract of Ishige okamurae, 3T3-L1 preadipocyte, Adipogenesis, Viability, Differentiation

\section{INTRODUCTION}

Adipogenesis from precursor cells has been extensively studied in order to overcome the physiological problems of obesity and its related diseases. This differentiation and homeostasis is under the control of various factors and complex processes (Cha et al., 2013; Park et al., 2013 a,b). Recently vigorous studies revealed various adipogenic factors such as dexamethasone, 3-isobutyl-1-methylxanthine, Dexras1, glucocorticoid, Notch 4, alpha-2-macrogloobulin, BMP4, Pref-1, paraoxonase/arylesterase 1, retinol, preadipocyte factor-1, Wnt (Cha et al., 2013; Lai et al., 2013; Muenzner et al., 2013; Park et al., 2013a; Gustafson \& Smith, 2012; Seres et al., 2010; Ross et al., 2000; Yeh et al., 1995; Smas \& Sul, 1993).

Adipocytes play a central role in maintaining lipid homeostasis and energy balance in vertebrates by storing triacylglycerols (TAGs) or releasing free fatty acids in response to changes in energy demands (Fruhbeck et al., 2001). However, the excessively grown adipose tissue in obesity is a major risk factor for a number of disorders, including diabetes, hypertension, and heart disease (Lee et

\footnotetext{
Manuscript received 30 November 2013, Received in revised form 16 December 2013, Accepted 21 December 2013

${ }^{\dagger}$ Corresponding Author : Yong-Pil Cheon, Division of Developmental Biology and Physiology, School of Biosciences and Chemistry, Sunghsin Women's University, Mia-Unjeong-Green Campus, 147 Mida-dong, Kangbuk-gu, Seoul 142-742, Republic of Korea. Tel. : +82-2-920-7639, Fax : +82-2-920-2093, E-mail: ypcheon@sungshin.ac.kr

This is an Open Access article distributed under the terms of the Creative Commons Attribution Non-Commercial License(http://creativecommons. org/licenses/by-nc/3.0) which permits unrestricted non-commercial use, distribution, and reproduction in any medium, provided the original work is properly cited.
} 
al., 2005). In addition, the economic costs associated with being overweight and obese are rising continuously and pose social problems (Fu et al., 2005b; Lee et al., 2005; Farmer \& Auwerx, 2004). The development of obesity is characterized by increased numbers of fat cells and their lipids due to the processes of mitogenesis and differentiation of adipocyte precursors, which are regulated by genetic, endocrine, metabolic, neurological, pharmacological, environmental, and nutritional factors (Fu et al., 2005a,b; Farmer \& Auwerx., 2004; Wang et al., 2001). Accordingly, an understanding of the mechanism through which a particular nutrient affects the mitogenesis of preadipocytes and their differentiation to adipocytes would help prevent the initiation and progression of obesity and its associated diseases in humans (Wang et al., 2001).

Brown algae synthesize and accumulate variety of biomolecules such as xanthophyll, pigments, fucoidans, phycocolloids, and phlorotannins. Several studies concerning these types of compounds have pointed out the variety of biological benefits, including antioxidant, anticoagulant, antihypertension, antibacterial, and antitumor activities. Ishige okamurae (Phylum Phaeophyta, Class Phaeophyceae, Order Chordariales, Family Ishigeaceae), an edible brown algae forming persistant populations in clear water, has been collected from the coast of Jeju island, Korea (Lee \& Kang, 1986). The extract of I. okamurae has been shown to have a variety of biological effects, including antioxidant effects (Kim et al., 2009), anti-viral effects (Ahn et al., 2002), apoptosis induction effect (Park et al., 2013b), and hypoglycemic effects (Min et al., 2011).

One of the known functions of the compound of $I$. okamurae is antiobesity (Jeon et al., 2013; Park et al., 2013a). Such antiobesity function is also known in the key compounds of some edible brown algae or extracts of them, such as Laminaria japonica (Shirosaki \& Koyama, 2011), Petalonia binghamiae (Kang et al., 2012), Undaria pinnatifida (Kim \& Lee, 2012). However, the role of the compounds of I. okamurae extract in adipogenesis is not much uncovered. In the present study, we examined the effects of the extract of I. okamurae on the diffe- rentiation of preadipocyte to adipocyte and accumulation of lipids.

\section{MATERIAL AND METHOD}

\section{Extraction of the extract of Ishige okamurae}

The extract of Ishige okamurae was performed at Seojjin Coorporation according to the established method (Heo et al., 2009). Briefly, the dried I. okamurae was exacted three times with $80 \%$ methanol and filtered. Then the filtrate was under evaporation at $40^{\circ} \mathrm{C}$. I. okamurae methanol extract was suspended on distiled water and the partitioned with ethyl acetate. The ethyl acetate fraction was subjected to silica gel and Sephadex-LH 20 column chromatography.

\section{Cell culture}

3T3-L1 fibroblast cells from the American Type Culture Collection (ATCC, USA) were maintained at $37^{\circ} \mathrm{C}$ in an incubator with a humidified atmosphere of $5 \% \mathrm{CO}_{2}$ and 95\% air. 3T3-L1 was cultured in Dulbecco's modified Eagle's medium-high glucose (DMEM-HG) (Gibco Cat\# 12800-58) containing 10\% bovine calf serum (FCS) (Gibco Cat\# 16170), $0.1 \mathrm{mg} / \mathrm{ml}$ streptomycin, $100 \mathrm{U} / \mathrm{ml}$ penicillin and $3.7 \mathrm{mg} / \mathrm{ml}$ sodium bicarbonate. Cells were seeded with $2.5 \times 10^{3}$ cells $/ \mathrm{cm}^{2}$ density in $100 \Phi$ cell culture dish. To prevent cell differentiation, cells were maintained at subconfluent levels. Medium was changed every 2-3 days.

\section{Cell viability}

The effect of the extract of Ishige okamurae on the viability of cells was determined using the [3-(4,5dimethylthiazol-2-yl)-2,5-diphenyltetrazolium] bromide (MTT) assay kit from Trevigen Inc. (Cat\# 4890-025-01), which is based on the reduction of a tetrazolium salt by mitochondrial dehydrogenase in viable cells (Carmichael et al., 1987). Cells were subcultured at 96-well plate, after $6 \mathrm{hr}$, cells were treated with caffeine $(0.05 \mathrm{mM}$ and $0.1 \mathrm{mM})$ and the extract of I. okamurae $(0.4 \mu \mathrm{g} / \mathrm{ml}, 2$ $\mu \mathrm{g} / \mathrm{ml}, 10 \mu \mathrm{g} / \mathrm{ml}, 50 \mu \mathrm{g} / \mathrm{ml})$. Then, $44 \mathrm{hr}$ later, added 10 $\mu \mathrm{l}$ of the MTT reagent and 2-4 hr later (until purple 
dye is visible.) added $100 \mu$ of the Detergent Reagent to all wells. After incubation for $2 \mathrm{hr}$, the optical density measured on $570 \mathrm{~nm}$ with spectrophotometer. Caffeine was used as a positive control in this study.

\section{Induction of 3T3-LI cell differentiation}

Culture and differentiation induction of 3T3-L1 cells was performed as described in ATCC (Student et al., 1980). Briefly, cells were subcultured with $2.5 \times 10^{3}$ cells/ $\mathrm{cm}^{2}$ density in 24-well plate in DMEM-HG containing $10 \%$ fetal calf serum (FCS). Induction was started after 2 days of $100 \%$ confluence. Media was changed with differentiation day 0 , differentiation medium (DMEM supplemented with $10 \%$ fetal bovine serum (FBS), 0.5 $\mathrm{mM}$ methylisobutylxanthine (IBMX), $1.7 \mu \mathrm{M}$ insulin, and $1.0 \mu \mathrm{M}$ dexamethasone). Caffeine (0.05 $\mathrm{mM}$ and 0.1 $\mathrm{mM})$ and the extract of $I$. okamurae $(0.4 \mu \mathrm{g} / \mathrm{ml}, 2 \mu \mathrm{g} / \mathrm{ml}$, $10 \mu \mathrm{g} / \mathrm{ml}$, and $50 \mu \mathrm{g} / \mathrm{ml}$ ) were added in the differentiation media to reveal their roles in adipogenesis. After 2 days, media were changed with adipocyte maintenance medium (DMEM supplemented with 10\% FBS, $1.0 \mu \mathrm{g} / \mathrm{ml}$ of insulin). Then, medium was replaced every 2-3 days until 10 days. We measured the degree of differentiation by Oil Red $\mathrm{O}$ staining and optical density.

5. Total RNA isolation and real-time polymerase chain reaction (PCR)

3T3-L1 cells were maintained in noninductive control medium until 90-95\% confluent the culture plate. The expression profiles of the adipogenesis marker genes were analyzed. Total RNAs from the cells on day 5 and ells were isolated using TRIzol Reagent according to the manufacturer's instructions. The purity of RNA was assessed by determining the ratio of absorbance at $260 \mathrm{~nm}$ to that at $280 \mathrm{~nm}$. First strand cDNA was synthesized using First-Strand synthesis kit (Stratagene, Cat \#. 200420) according to the manufacturer's instructions. Briefly, the mixtures were incubated at $65^{\circ} \mathrm{C}$ for minutes and place tube at room temperature for 10 minutes for the primers to anneal to the RNA. And incubated at $42^{\circ} \mathrm{C}$ for 60 minutes and incubated at $70^{\circ} \mathrm{C}$ for 15 minutes to terminate cDNA synthesis. Quantitative real-time PCR was performed for peroxisome proliferator activated receptor gamma (Pparg), lipoprotein lipase (Lpl), adiponectin (AdipoQ), and acidic ribosomal phosphoprotein P0 (36B4, Rplp0). Rplp0 was used as internal control. The primers (Bioneer, Koear) were depicted in Table 1.

6. Morphological examination and measure the amount of stained lipids

After induction, the cells were washed with phosphatebuffered saline (PBS). The cells were fixed with $0.4 \%$ formaldehyde in room temperature for $10 \mathrm{~min}$, and then briefly washed with $\mathrm{H}_{2} \mathrm{O}$. The cells were stained with freshly prepared Oil Red O solution for $1 \mathrm{hr}$. The morphology was analyzed with microscope. To measure the stained lipids, Oil Red O dye were eluted with isopropanol. After elution, the solution was transferred to 96-culture

Table 1. Sequences of primers

\begin{tabular}{cll}
\hline Genes & Gene bank access No. & SeQuences \\
\hline \multirow{2}{*}{ Rplp0 } & NM_007475 & S: CGACCTGGAAGTCCAACTACTTCCT \\
& MMU01841 & AS: ATGCTGTTGGCCCAAATAAGGTGC \\
\hline PPAR r & S: AGACCACTCGCATTCCTTTGAC \\
\hline LPL & NM_008509 & AS: TGCTTTATCCCCACAGACTCG \\
\hline \multirow{2}{*}{ Adiponectin } & S: GGACGGTAACGGGAATGTATGA \\
\hline \multirow{2}{*}{ NM_009605 } & AS: ATCAGCGTCATCAGGAGAAAGG \\
\hline
\end{tabular}


dish and measured the optical density (500 nm) with microplate reader.

\section{Statistical analysis}

The data represent means \pm SED. The data were analyzed using one-way analysis of variance (ANOVA) and $t$-test. In all cases, $p$ values $<0.05$ were deemed to indicate statistical significance.

\section{RESULT}

1. The extract of Ishige okamurae modified the viability of 3T3-L1 cells

The effects of the extract of $I$. okamurae on the viability of 3T3-L1, a preadipocyte, were analyzed with MTT assay as mentioned in Materials and Methods. As expected, the viability of 3T3-L1 was not inhibited by caffeine. The viability was significantly higher $(p<0.05)$ in 0.1

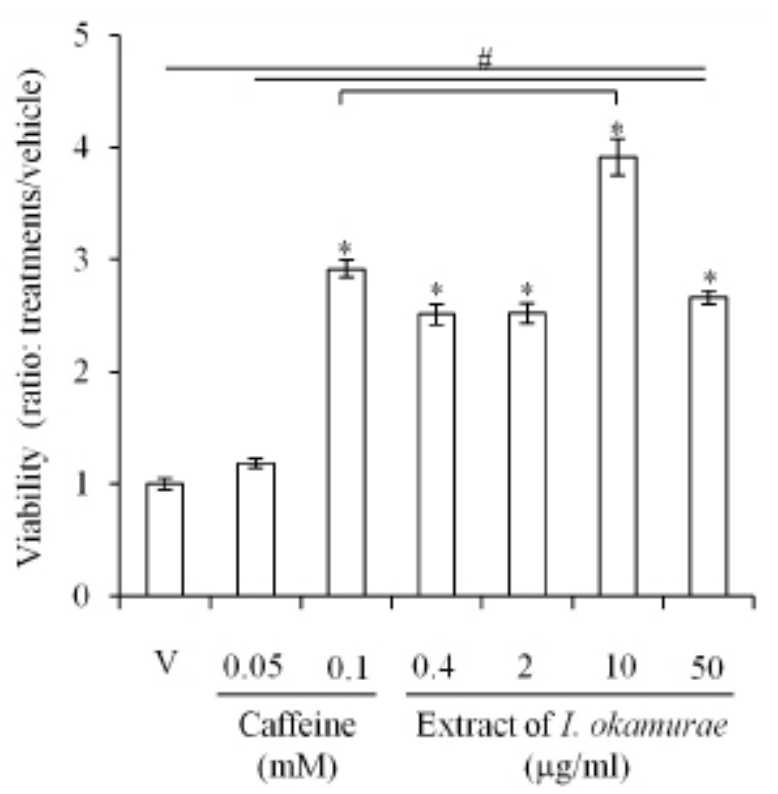

Fig. 1. Improvement in the viability of 3T3-L1 by the extract of Ishige okamurae in standard culture condition. 3T3L1 cells were cultured in the media containing various concentration of caffeine and the extract of Ishige okamurae. Viability of the cells was analyzed by MTT assay. Each experiment was repeated at least 3 times and the individual values represent mean \pm SD. $(*, \# p<$ 0.05 ; vehicle vs experiment).
$\mathrm{mM}$ caffeine treated cells (Fig. 1). However, in all groups treated with extract of $I$. okamurae $(0.4-50 \mu \mathrm{g} / \mathrm{ml})$, the viability of 3T3-L1 was significantly higher $(p<0.05)$ than the vehicle. In the case of $10 \mu \mathrm{g} / \mathrm{ml}$ group, the viability was significantly higher than that of $0.1 \mathrm{mM}$ caffeine group (Fig. 1).

2. The extract of Ishige okamurae modified the differentiation of 3T3-L1 cell line.

Lipids accumulated in the cells which were induced for adipogenesis from 3T3-L1 preadipocyte (Fig. 2A). Caffeine was used as a control for the inhibition of adipogenesis of 3T3-L1 and accumulation of lipids in differentiating cell. As expected, Oil Red O was stained in most cells of vehicle (Fig. 2A2). The specific ranges of concentration $(0.4-2 \mu \mathrm{g} / \mathrm{ml})$ of $I$. okamurae extract did not inhibit accumulation of lipids in the differentiated cells (Fig. 2A2,3). In $10 \mu \mathrm{g} / \mathrm{ml}$ I. okamurae extract group, the number of cells which accumulate lipids was little bit decreased but not distinguishable (Fig. 2A4). However, the number of cells which was accumulated with lipids was decreased in $50 \mu \mathrm{g} / \mathrm{ml}$ I. okamurae extract (Fig. 2A5).

Interestingly, the optical density of the extracted Oil Red $\mathrm{O}$ from the stained cells was significantly decreased both in 10 and $50 \mu \mathrm{g} / \mathrm{ml} \mathrm{I}$. okamurae extract. However, the optical density was increased in the low concentration groups (Fig. 2B). In the caffeine control, the optical density was not affected: there was no statistical significance (Fig. 2B). These results suggested that the differentiation or accumulation of lipids is modified by the extract of I. okamurae.

3. The extract of Ishige okamurae modified adipogenesis of 3T3-L1 cell line.

Based on the morphology of the differentiated cells, we analyze the expression profiles of some of the well known adipogenic marker genes. Its expression was increased by the adipogenesis induction of 3T3-L1 preadipocyte. The expression profiles of Pparg mRNA in the group treaed with $I$. okamurae were different from the vehicle 
A
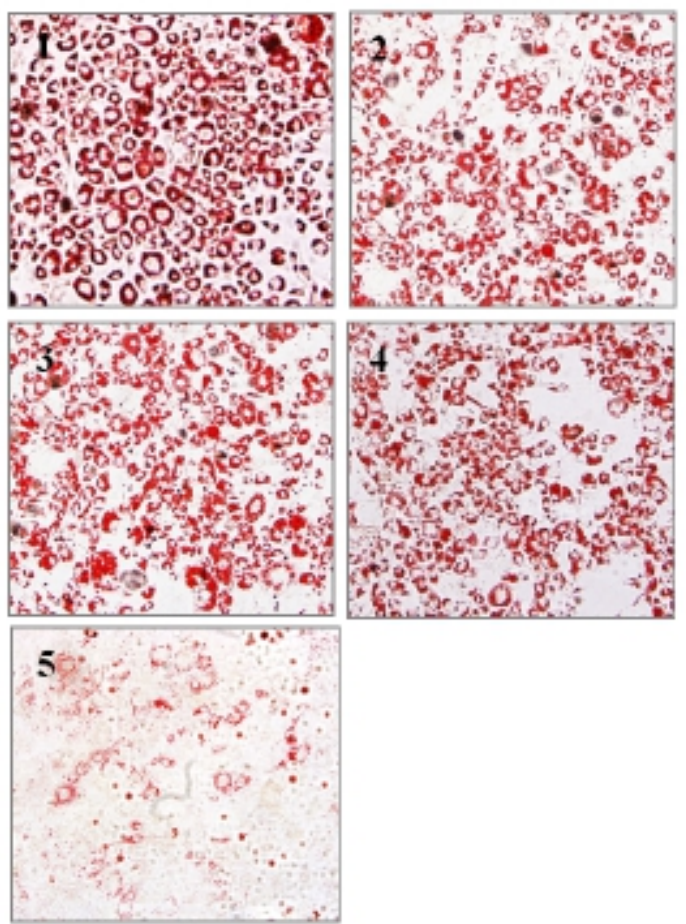

B

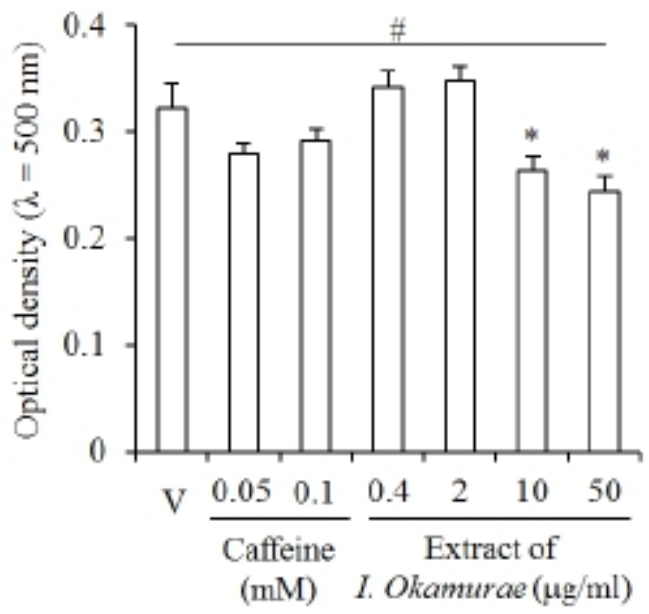

Fig. 2. The extract of Ishige okamurae suppresses the accumulation of lipids during adipogenesis of 3T3-L1 preadipocyte.

The photomicrograph of the cells which were induced adipogenesis from 3T3-L1 preadipocyte (A): 1 is the photomicrograph for vehicle; 2 is the photomicrograph for $0.1 \mathrm{mM}$ caffeine; 3 is the photomicrograph for $2 \mu \mathrm{g} /$ $\mathrm{ml}$ extract of I. okamurae; 4 is the photomicrograph for $10 \mathrm{\mu g} / \mathrm{ml}$ extract of I. okamurae; 5 is the photomicrograph for $50 \mathrm{\mu g} / \mathrm{ml}$ extract of $I$. okamurae. Optical density of the extracted Oil Red $\mathrm{O}$ was measured with microplate reader (B). Each experiment was performed at least 3 times and the individual values are expressed as mean \pm SD. (*, \# $p<0.05$; vehicle vs experiment).
A

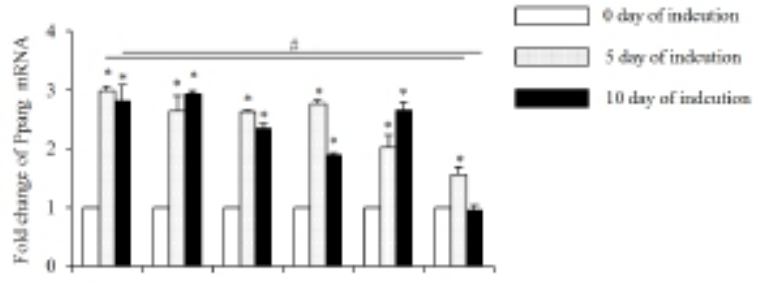

B

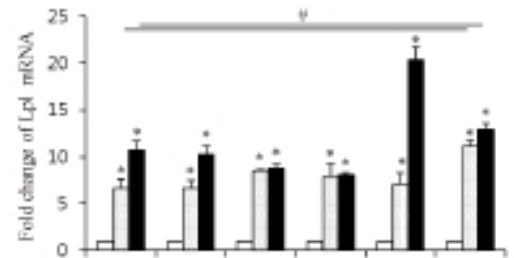

$\mathrm{C}$

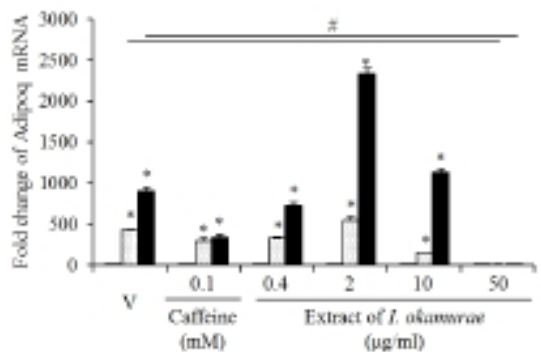

Fig. 3. Expression profiles of adipogenic genes. The profiles of gene expression were analyzed using real-time PCR method. Rplp0 was used as internal control. Each experiment was performed at least 3 times and the individual values are expressed as mean \pm SD. $(*, \# p<$ 0.05 ; vehicle vs experiment).

and caffeine treated groups (Fig. 3A). The expression levels of Pparg mRNA were not different from the vehicle both in 5 days and 10 days of induction. The levels of Pparg mRNA expression were decreased by the extract of $I$. okamurae in a concentration dependent manner until 5 days of induction. The expression levels continuously maintained until 10 days of induction in control and caffeine treated cells, but their levels were decreased after 5 days of induction in the I. okamurae extract treated cells. Especially, the expression levels were significantly decreased in $50 \mu \mathrm{g} / \mathrm{ml} \mathrm{I}$. okamurae extract both 5 and 10 days of induction (Fig. 3A).

Lp1 mRNA expression was modified by the extract of I. okamurae. Its expression was increased by the adipogenesis induction of 3T3-L1 preadipocyte. On day 5 of adipogenesis induction, the expression levels 
of Lpl mRNA were similar between the caffeine and $0.4-10 \mu \mathrm{g} / \mathrm{ml} \mathrm{I}$. okamurae extract, and the vehicle treated cells. However, its expression level was significantly high in $50 \mu \mathrm{g} / \mathrm{ml}$ I. okamurae extract treated cells on day 5 of induction. The expression of Lpl was continuously increased in all groups until day 10 of adipogenesis induction. Lp1 mRNA expression levels were significantly higher in $50 \mathrm{\mu g} / \mathrm{ml} \mathrm{I}$. okamurae extract both 5 and 10 days of induction (Fig. 3B).

The expression profiles of AdipoQ mRNA were also modified by the extract of I. okamurae. Its expression was increased by adipogenesis induction of 3T3-L1 preadipocyte. On day 5 of adipogenesis induction, the expression levels were significantly low in all groups except $2 \mu \mathrm{g} / \mathrm{ml}$ I. okamurae extract treated group. Its expression levels continuously increased only in all caffeine treated groups and 0.2-0.4 $\mathrm{\mu g} / \mathrm{ml}$ I. okamurae extract treated group. On day 10 of adipogenesis induction, the expression levels were significantly increased in 2 and $10 \mu \mathrm{g} / \mathrm{ml} \mathrm{I}$. okamurae extract treated group. In 50 $\mu \mathrm{g} / \mathrm{ml}$ I. okamurae extract treated cells, the expression levels of AdipoQ were lower than that of control and other groups both in 5 day and 10 day of adipogenesis induction (Fig. 3C).

\section{DISCUSSION}

Obesity became a social problem in industrialized countries and many studies extremely tried to solve that problem. However, it is until now far from the goal. The physiological problems derived from overaccumulation of nutrients are one of the major disorders. During development, increase of the number of adipocyte and the size of adipocytes in a specific body site is a way to forming organ and body shapes. Increases in the size of adipose tissue is achieved both by increase in the number of adipocyte and the differentiation of preadipocyte to adipocyte. Growth of white adipose tissue and defects in adipogenesis are critical in energy balance and production of signal molecules (Xue et al., 2013). Hypertrophic obesity in the abdominal subcutaneous tissue is characterized by a reduced recruitment of new adipose cells by the reduced preadipocytes (Amer et al., 2010; Spalding et al., 2008). It is suggested that reduction in the recruited preadipocyte is due to an apparent genetic impairment in the ability to recruit and differentiate (Gustafson \& Smith, 2012; Arner et al., 2011; Jansson et al., 2003). Therefore, it is important to keep the optimal number of preadipocyte or adipose stem cell for health life. It has been tried to regulate the growth of adipose tissue through several ways such as suppression of food intake and digested energy source absorption, inhibition of preadipocyte proliferation and of differentiation. So far, not much is known for the mechanisms for commitment of mesenchymal stem cells to preadipocytes, but the differentiation of preadipocytes to adipocytes is cleared. Differentiation of preadipcyte is regulated by complicated networks of transcription factors, including CCAAT/enhancerbinding proteins and peroxisome proliferator-activated receptor $\gamma$ protien (PPAR $\gamma$ ) (Chen et al., 2013a; Lefterova \& Lazar, 2009; Tontonoz \& Spiegelman, 2008).

The suppression of the activity of antioxidant response element (ARE) with isoniazid interrupts the transcriptional network of adipogenesis and leading to impaired adipogenic differentiation (Chen et al., 2013b). Recently, it is suggested that utilization of natural sources is helpful to reducing obesity. We performed this study to get possible approach reducing adipose tissue size or growth with natural sources. One of the well established model in the study of differentiation and triglyceride accumulation is 3T3-L1 preadipocyte (Chen et al., 2013a,b). The cellular activity was significantly increased in the cells treated with the extract of I. okamurae compared with the control. Caffeine also increased the cellular activity in concentration dependent manners. High level of ATP in preadipocyte means that cells can achieve proliferation or differentiation.

Low concentration of I. okamurae extract did not inhibit accumulation of lipids in the differentiating cells but high $(50 \mu \mathrm{g} / \mathrm{ml})$ I. okamurae extract inhibited lipid accu- 
mulation. It means that the differentiation or accumulation of lipids is modified by the extract of I. okamurae in a concentration dependent manner. Differentiation of preadipocyte to adipocyte reQuires the concerted regulation of gene expression by various adipogenic factors. Among them, hormone nuclear receptor PPAR $\gamma$ plays central roles by controlling down stream adipogenic genes (Farmer, 2006; Tontonoz et al., 1994). The expression levels of Pparg mRNA were decreased by the extract of $I$. okamurae in a concentration dependent manner until 5 days of adipogenesis induction. Especially, the expression levels were significantly decreased in $50 \mu \mathrm{g} / \mathrm{ml}$ I. okamurae extract until differentiation. AdipoQ encodes adiponectin which is involved in the regulation of glucose level and breakdown of fatty acid. The roles of adiponectin also include the promotion of adipocyte differentiation and lipid accumulation (Fu et al., 2005a). The expression levels of AdipoQ mRNA were significantly decreased during adipogenesis by high concentration of the extract of I. okamurae. Lpl encodes liporotein lipase which has dual functions of triglyceride hydrolase and ligand/ bridging factor for receptor-mediated lipoprotein uptake. Lpl expression is increased during adipogenesis (Ullah et al., 2013). The expression levels of Lp1 mRNA were increased until day 10 of adipogenesis induction. Based on these results we can suggest that the extract of $I$. okamurae can suppress preadipocyte differentiation and accumulation of lipids in a concentration dependent manner without reducing viability of preadipocytes. In murine 3T3-L1 preadipotyes, caffeine does not inhibit differentiation to adipocyte but it suppresses the intracellular lipoid accumulation (Riedel et al., 2012; Nakabayashi et al., 2008). In the result, caffeine did not inhibit Pparg and Lpl mRNA expression, but AdipoQ mRNA expression. Base on them, it is suggested that the extract of I. okamurae contain compound decreasing the competence of preadipocyte for adipogenesis.

With 3T3-L1 model, it is revealed that Wnt/b-catenin signaling pathway is a key signaling pathway in differentiation of 3T3-L1 cells into adipocytes (Chen et al., 2013a). Notch4 signaling pathway is known adipogenesis pathway. It promotes facilitated differentiation of 3T3-L1 cells through modulating the ERK pathway and upregulating adipogenic genes such as $\mathrm{C} / \mathrm{EBP} \alpha, \operatorname{PPAR} \gamma$, aP2, LPL, and HSL during the middle and late stages of 3T3-L1 adipogenesis (Lai et al., 2013). So far, it is not explored what is the mediator of the work of the extract of $I$. okamurae or its key molecules. However, it is clearly revealed that the extract of I. okamurae have antiobesity role without reducing the viability of preadipocyte, 3T3-L1. It has various important meaning for such as treatment obesity with conserving preadipocte. In addition, it will provide a plausible way to regulate the growth of adipose tissue. Further investigations will clarify the current situation which is ongoing in our group.

\section{ACK NOWLEDGEMENTS}

This research was supported by 2013 Research Grant from Sungshin Women's University.

\section{REFERENCES}

Ahn MJ, Yoon KD, Kim CY, Min SY, Kim Y, Kim HJ, Kim JH, Shin CG, Lee CK, Kim TG, Kim SH, Huh H, Kim J (2002) Inhibition of HIV-1 reverse transcriptase and HIV-1 integrase and antiviral activity of Korean seaweed extracts. J Appl Phycol 14:325329.

Amer E, Westermark PO, Spalding KI, Britton T, Ryden M, Frisen J, Bernard S, Amer P (2010) Adpocyte turnover: relevance to human adipose tissue morphology. Diabetes 59:105-109.

Arner P, Arner E, Hammarstedt A, Smith U (2011) Geneti predisposition for type 2 diabetes, but not for overweight/obesity, is associated with a restircted adipogenesis. Plos ONE 6:318284.

Cha JY, Kim HJ, Yu JH, Xu J, Kim D, Paul DB, Choi H, Kim S, Lee YJ, Ho GP, Rao F, Snyder SH, Kim JW (2013) Dexras1 mediates glucocorticoid-associated 
adipgenesis and diet-induced obesity. Proc Natl Acad Sci U S A 110:20575-20580.

Chen $\mathrm{H}$, Wang S, Chen L, Chen Y, Wu M, Zhang Y, Yu K, Huang Z, Qin L, Mo D (2013a) MicroRNA344 inhibits 3T3-L1 cell differentiaiton via targeting GSK3 $\beta$ of Wnt/ $\beta$-catenin signaling pathway. FEBS Lett.

Chen Y, Xue P, Hou Y, Zhang H, Zheng H, Zhou T, Qu W, Teng W, Zhang Q, Andersen ME, Pi J (2013b) Isoniazid suppresses antioxidant response element activities and impairs adipogenesis in mouse and human preadipocytes. Toxicol Appl Pharmacol 273:435-441.

Farmer SR (2006) Transcriptional control of adipocyte formation. Cell Metab 4:263-273.

Farmer SR, Auwerx J (2004) Adipose tissue: new therapeutic targets from molecular and genetic studiesIASO Stock Conference 2003 report. Obes Rev 5: 189-196.

Fruhbeck G, Gomez-Ambrosi J, Muruzabal FJ, Burrel MA (2001) The adipocyte: a model for integration of endocrine and metabolic signaling in energy metabolism regulation. Am J Physiol Endocrinol Metab 280:E827-47.

Fu Y, Luo N, Klein RL, Garvey WT (2005a) Adiponectin promotes adipocyte differentiation, insulin sensitivity, and lipid accumulation. J Lipid Res 46:1369-1379.

Fu J, Oveisi F, Gaetani S, Lin E, Piomelli D (2005b) Oleoylethanolamide, an endogenous PPAR-alpha agonist, lowers body weight and hyperlipidemia in obese rats. Neuropharmacology 48:1147-53.

Gustafson B, Smith U (2012) The WNT inhibitor Dickkopf1 and bone morphogenetic protein 4 rescue adipogenesis in hypertrophic obesity in humans. Diabetes 61:12171224.

Heo, SJ, Hwang JY, Choi JI, Han JS, Kim HJ, Jeon YJ (2009) Diphlorethohydroxycarmalol isolated from Ishige okamurae, a brown algae, a potent alphaglucosidase and alpha-amylase inhibitor, alleviates postprandial hyperglycemia in diabetic mice. Eur $\mathrm{J}$ Pharmacol 615:252-256.
Jansson PA, Pellmé F, Hammarstedt A, SandQist M, Brekke H, Caidahl K, Forsberg M, olkmann R, Carvalho E, Funahashi T, Matsuzawa Y, Wiklund O, Yang X, Taskinen MR, Smith U (2003) A novel cellular marker of insulin resistance and early atherosclerosis in humans is related to impaired fat cell differentiation and low adiponectin. FASEB J 17:1434-1440.

Jeon Y, Song S, Kim H, Cheon YP (2013) Diphlorethohydroxycarmalol of Ishige okamurae and caffeine moidfied the expression of extracellular fibrillars during adipogenesis of mouse subcutaneous adipose derived stem cell. Dev Reprod 17:275-287.

Kang SI, Shin HS, Kim HM, Yoon SA, Kang SW, Kim JH, Kim SJ (2012) Pepalonia binghamiae extract and its constituent fucoxanthin ameliorate high-fat diet-induced obesity by activating AMP-activated protein kinase. J Agric Food Chem 60:3389-3395.

Kim KJ, Lee BY (2012) Fucoidan form the sporophyll of Undaria pinnatifida suppresses adipocyte differentiation by inhibiton of inflammation-related cytokines in 3T3L1 cells. Nutr Res 32:439-447.

Kim MM, Rajapakse N, Kim SK (2009) Anti-inflammatory effect of Ishige okamurae ehtanolic extract via inhibition of NF-kappaB transcription factor in RAW 264.7 cells. Phytother Res 23:628-634.

Lai PY, Tsai CB, Tseng MJ (2013) Active form Notch4 promotes the proliferation and differentiation of 3T3-L1 preadipocytes. Biochem Biophys Res Commun 430: 1132-1139.

Lee IK, Kang JW (1986) A check list of marine algae in Korea. Algae 1:311-325.

Lee WJ, Koh EH, Won JC, Kim MS, Park JY, Lee KU (2005) Obesity: the role of hypothalamic AMPactivated protein kinase in body weight regulation. Int J Biochem Cell Biol 37:2254-2259.

Lefterova MJ, Lazar MA (2009) New developments in adipogenesis. Trends Endocrinol Metab 20:107-114.

Min KH, Kim HJ, Han JS (2011) Ishige okamurae ameliorates hyperglycemia and insulin resistance in C57BL/KsJ-db/db mice. Diabetes Res Clin Pract 93: 
70-76.

Muenzner M, Tuvia N, Deutschmann C, Witte N, Tolkachov A, Valai A, Henze A, Sander LE, Raila J, Schupp M (2013) Retinol-dinding protein 4 and its membrane receptor STRA6 control adipogenesis by regulating cellular retinoid homeostasis and retinoic acid receptor $\alpha$ activity. Mol Cell Biol 33:4068-4082.

Nakabayashi H, Hashimoto T, Ashida H, Nishiumi S, Kanazawa K (2008) Inhibitory effects of caffeine and its metabolites on intracellular lipod accumulation in murine 3T3-L1 adipocytes. BioFactors 34:293-302.

Park J, Park J, Nahm SS, Choi I, Kim I (2013a) Identification of anti-adipogenic proteins in adult bovine serum suppressing 3T3-L1 preadipocyte differentiation. BMB Rep 46:582-587.

Park MH, Jeon YJ, Kim HJ, Han JS (2013b) Effect of diphlorethohydroxycarmalol isolated from Ishie okamurae on apoptosis in 3 T3-L1 preadipocytes. Phytother Res 27:931-936.

Riedel A, Pignitter M, Hochkogler CM, Rohm B, Walker J, Bytof G, Lantz I, Somaza V (2012) Caffeine dosedependently induced thermogenesis but restores ATP in HepG2 cells in culture. Food Funct 3:955-964.

Ross SE, Hemati N, Longo KA, Bennett CN, Lucas PC, Erickson RL, MacDougald OA (2000) Inhibition of adipogenesis by Wnt signaling. Science 289:950-953.

Seres I, Bajnok L, Harangi M, Sztanek F, Koncsos P, Paragh G (2010) Alteration of PON1 activity in adult and childhood obesity and its relation to adipokine levels. Adv Exp Med Biol 660:129-142.

Shirosaki M, Koyama T (2011) Laminaria japonica as a food for the prevention of obesity and diatetes. Adv Food Nutr Res 64:199-212.

Smas CM, Sul HS (1993) Pref-1, a protein containing
EGF-like repeats, inhiits adipocyte differentiation. Cell 73:725-734.

Spalding KL, Arner E, Westermark PO, Bernard S, Buchholz BA, Bergmann O, BlomQvist L, Hoffstedt J, Naslund E, Britton T, Concha H, Hassan M, Ryden M, Frisen J, Arner P (2008) Dynamics of fat cell turnover in humans. Nature 453:783-787.

Student AK, Hsu RY, Lane MD (1980) Induction of fatty acid synthetase in differentiating 3T3-L1 preadipocytes. J Biol Chem 255:4745-4750.

Tontonoz P, Hu E, Spiegelman BM (1994) Stimulation of adipogenesis in fibroblasts by PAR gamma 2, a lipid-activated transcription factor. Cell 79:1147-1156.

Tontonoz P, Spiegelman M (2008) Fat and beyond: the diverse biology of PPARgamma. Annu Rev Biochem 77:289-312.

Ullah M, Stich S, Haupl T, Eucker J, Sittinger M, Ringe J (2013) Reverse differentiation as a gene filtering tool in genome expression profiling of adipogenesis for fat marker gene selection and their analysis. PLOS One 8:e69754.

Wang ZW, Pan WT, Lee Y, Kakuma T, Zhou YT, Unger $\mathrm{RH}$ (2001) The role of leptin resistance in the abnormalities of aging. FASEB J 15:108-114.

Xue P, Hou Y, Chen Y, Yang B, Fu J, Zheng $\mathrm{H}$, Yarborough K, Woods CG, Liu D, Yamamoto M, Zhang Q, Andersen ME, Pi J (2013) Adipose dificinecy of Nrf2 in ob/ob mice results in severe metabolic syndrome. Diabetes 62:845-854.

Yeh WC, Cao Z, Classon M, McKnihgt SL (1995) Cascade regulation of terminal adipocyte differentiation by three members of the C/EBP family of leucine zipper proteins. Genes Dev 9:168-181. 